\title{
BLENDED LEARNING AND EXTENSIVE LISTENING: A PROMISING COLLABORATION TO ENHANCE LISTENING SKILL
}

\author{
Fitri Awaliyatush Sholihah \\ fitriawaliy@unisma.ac.id \\ Universitas Islam Malang \\ Mukhamad Bayu Permadi \\ bayoelit89@yahoo.co.id \\ Universitas Islam Malang \\ Atik Umamah \\ atikumamah@unisma.ac.id \\ Universitas Islam Malang
}

\begin{abstract}
This research aimed at describing how blended learning strategy by integrating portfolio-based extensive listening activity can improve students' listening skill. This action research was the response of the classroom problem identified in Listening 2 course in class 2E of English Department, Universitas Islam Malang. The problem was the average score of this class was low (68.86) and only $45 \%$ of the students achieved the standard minimum score $(\geq 75)$. Data from interview uncovered that the major cause was insufficient exposure to authentic listening input. The instruments used to gain the data were portfolio and test. The criterion of success set was that $70 \%$ of the students obtained the standard minimum score. This research was conducted in two cycles with four meetings for each. At the end of cycle 1, the average score was 75.36 but only $55 \%$ of the students achieved the standard minimum score. The test result in cycle 2 indicated that the average score was 78.36 and $73 \%$ of the students reached the standard minimum score, meaning that the criterion of success was achieved. This implies that the implementation of blended learning approach with portfolio-based extensive listening activity can significantly enhance listening skill.
\end{abstract}

Keywords:listening skill, blended learning, extensive listening, portfolio

\section{BACKGROUND}

Blended learning (BL), interchangeably with the term hybrid learning, mixed learning or b-learning, is actually not a new paradigm in English language teaching context since this kind of learning model had been initiated with the emergence of CALL (Computer-assisted Language Learning). This learning model, however, grabs much greater demand in today's learning due to the advancement in the world of technology especially in terms of network tools. It is like what Yen and Lee (2011) state "blended learning, thoughtfully combining the best elements of online and face-to-face education, is likely to emerge as the predominant teaching model of the future" (cited in Poon, 2013).

According to Stracke (2007), blended learning is defined as the utilization of computer in the process of teaching and learning. Grgurović(2011), in addition, states that blended learning refers to conventional teaching and learning process with online activity as supplement. Further, Abdullah (2015) points out that the mix of online-based learning 
taken place outside the class without leaving face-to-face classroom learning mode is the definition of blended learning. From some definitions proposed, blended learningthen can be referred to the blend modes of traditional face-to-face learning in the classroom and online activityoutside the class intended to direct learners to attain better enhancement in their learning process.

Based on Department of Defense Education Activity (DoDEA), blended learning can be executed in different models such as1) full online curriculum with classroom meeting as the option, 2) mostly online with some required face-to-face activities in the classroom or computer lab, 3) mostly online activities with daily meetings held in computer lab or classroom, 4) mostly classroom instructions with some online activities done outside the class, and 5) mostly face-to-face activities combined with online resources and limited online activities (cited in Abdullah, 2015).From the various models, it can be inferred the prominent role of face-to-face activities, which seem to be maintained though in a different degree of time. In other words, there is a seamless link between the two, and they play the same important role. This what makes blended learning differs from distance learning, mainly conducted in online mode without face-to-face interaction. The failure of distance learning, according to Stracke (2007), "points to the irreplaceable human component in any learning experience that cannot be ignored, but must form part of the learning experience." It is, therefore, learning with blend mode is regarded to be more effective and more appropriate with today's education challenge.

Graham, Allen, and Ure (cited in Graham, 2006), propose three main reasons why blended learning gains favorable response: (1) it promotes pedagogical improvement, (2) it offers an increase in access/flexibility, and (3) it provides cost effectiveness (cited in Stracke, 2017). Further, based onsome research findings, blended learning is found to provide a more effective English teaching and learning (Bañados, 2006), to promote the four English skillsdevelopment (Banditvilai, 2016) in particular listening skill (Abdullah, 2015; Lebedeva, et.al., 2017), to encourage autonomous learning and to construct motivation (Banditvilai, 2016), and to build responsibility (CondruzBăcescu, 2012).

In EFL context, where theoretically it is quite challenging for learners to expose themselves with English experience, the proliferation of Internet access has opened possibilities and expectations for a more flexible and personalizedEnglish language learning more specifically in the teaching and learning of listening skill. Improvement on this skill according to Richards (2005) is strongly required since it provides a great advantage for not only the listening itself but also other skills such as speaking and reading.In this sense, the integration of online activities through blended learning in listening class will provide learners with unlimited authentic exposure to listen to various and rich aural texts in the target language.

With regard to this topic, some researchcarried out the last few years underscore the potential role of blended learning in this aural skill. The first to mention is from Bañados (2006), who applied UdeC English Online, a software created for Communicative English Program at the Universidad de Concepción, Chile. After piloting this software through blended learning, it can be concluded that this kind of learning model leads to the students' language skill enhancement and the students' satisfaction. In addition, Abdullah (2015) investigatesthe effect of suggested blended learning strategy on the postgraduate nonEnglish students' listening comprehension ability. Adopting quasi-experimental design, this research reveals that blended learning can significantly improve not only the students' listening comprehensionbut also their general English learning. Further, this research highlights some factors to contribute to the positive result such as explicit and clear 
instruction, modeling, and guided practice. Those structured activities assist the students to complete the task given more easily.

Similar result is reported by Banditvilai (2016), who examines the implementation of blended learning in English classroom context in Thailand. This research confirms the influential role of this learning model in all the four English skills especially related to the students' motivation and autonomy. Moreover, the students also express positive attitude toward the implementation of blended learning. In line with the previous research, Alshaikhi and Madini, (2016), who investigate female students' perception on the use of Podcasts to improve extensive listening in Saudi, also report that the students perceive a positive perception.

In Russia, Lebedeva at.al (2017) examined the application on blended learning based on the purpose of listening skill; listening for general information and selective listening. The finding indicates positive effect particularly on the shaping of selective listening skills. With respect to the students' perception, this research also highlights the satisfactory feeling of using combined learning.

Considering the review above, it is worth to adopt blended learning approach in the researcher's listening class, in which most of the students dealt with listening problem. The problem was the average score of this class was low (68.86) and only $45 \%$ of the students achieved the standard minimum score $(\geq 75)$. Data from interview in the preliminary study uncovered that the major source of the difficulty was insufficient exposure to authentic listening input resulting in unfamiliarity with English pronunciation and vocabulary typical problems encountered by EFL learners (Hamouda, 2013). The vast majority of them said that they mainly practiced listening in the classroom. It is, therefore, crucial to bridge the distance between target language exposure and listening course, and one of the promising ways is through the integration of extensive listening.

Not few research reports on extensive listening have been published, and mostly confirm the positive effect on the improvement of listening skill (Reinders\&Cho, 2010; Onoda, 2012; Chang\&Millett, 2013; Hapsari\&Ratri, 2013; Mayora, 2017). Investigating Turkish college students, Bozan (2015) reports the significant role of extensive listening on the students' overall English skills, proficiency level and motivation for a more sustainable learning. Interestingly, this experimental research also uncovered positive correlation between extensive listening and proficiency level, meaningthat the more frequently students engage themselves in extensive listening activities, the more improvement on their global language skills they obtain. Unfortunately, those studies did not assign the students to hand in structured and formal report for their extensive listening activities. Ducker (2013) then proposes the use of portfolio in extensive listening activities; however, it was not really effective as only $50 \%$ of the students make the portfolio. It occurs because the students are not obliged to do so. The researcher states the importance of obliging the students to make the portfolio as the recommendation for future research.

Taking this consideration into account, this current research is carried out to describe the implementation of blended learning approach by integrating portfolio-based extensive listening to optimize the students' aural skill.The context of this research tends to apply a kind of blended learning taking place mostly in face-to-face mode, while the online activities are in the form of extensive listening activities assignedas a structured weekly assignment. Therefore, the online session is generally done beyond the class with further discussion conducted in the classroom. 


\section{METHOD}

As the response toward the problem appearing in the classroom context, this research applied classroom action research (CAR) in nature. The classroom problem identified was in Listening 2 course in class 2E of English Department, Universitas Islam Malang. The instruments used to gain the data were portfolio and test. Portfolio was used to provide the students with clear instructions so that they could learn in a more structured way. In the portfolio, they were assigned to write down their identity, topic based on the vote result, date, the title of the audio/video, the source of the audio/video, the listening frequency, new vocabulary, summary, and things they consider interesting.

The second instrument was test administered at the end of the cycle - four meetings for each. A-40 items of test in the forms of filling the blanks, rearranging text, and responding True or False were prepared. It was intended to measure whether there was an improvement on the students' listening skill. The criterion of success set was that $70 \%$ of the students obtained the standard minimum score $(\geq 75)$.

The main instructions for the extensive listening activities given to the students are in the following. 1) The students were given a soft file of the portfolio format. 2) They voted to decide the topic they were going to listen as the assignment. 3) They were asked to listen to at least three audios/videos they selected themselves as frequently as they needed. 4) They had to fill out the portfolio. 5) They must write down their summary based on what they heard without reading transcription (they were convinced that the summary did not have to be correct). 6) They were allowed to read the transcription for comprehension check after making summary. 7) They had to turn in the soft file of the audio/video with the printed portfolio every meeting.

\section{FINDINGS AND DISCUSSION Findings}

This research was finally conducted in two cycles, and as stated earlier each cycle consisted of four meetings. Detailed explanation of each cycle is elaborated in the following section.

\section{Cycle 1}

At the end of Cycle 1, a listening test was performed to measure the students' improvement. As it can be seen in Table 1, the result showed that the students' average score is 75.36 , and only 12 out of 22 students achieved the score of at least 75 meaning that $55 \%$ of the students achieved the standard minimum score. It means that the criterion of success has not been achieved yet, and Cycle 2 must be conducted.

Table 1 Students' Test Score in Cycle 1

\begin{tabular}{|c|c|c|}
\hline NO. & NAME & SCORE \\
\hline 1 & DAM & 73 \\
\hline 2 & RWP & 63 \\
\hline 3 & GAH & 87 \\
\hline 4 & $\mathrm{~N}$ & 78 \\
\hline 5 & QA & 92 \\
\hline 6 & IM & 59 \\
\hline 7 & $\mathrm{PMH}$ & 73 \\
\hline 8 & $\mathrm{SM}$ & 77 \\
\hline 9 & ARD & 82 \\
\hline
\end{tabular}




\begin{tabular}{clc}
\hline 10 & TW & 87 \\
\hline 11 & DH & 78 \\
\hline 12 & TW & 82 \\
\hline 14 & DM & 75 \\
\hline 15 & FHA & 50 \\
\hline 16 & IS & 97 \\
\hline 17 & S & 68 \\
\hline 18 & AM & 70 \\
\hline 19 & ES & 75 \\
\hline 20 & NSS & 73 \\
\hline 21 & NCH & 66 \\
\hline 22 & VAF & 86 \\
\hline $\begin{array}{c}\text { Average } \text { Score } \\
\text { Percentage }(\%) \\
\text { (The score } \text { of } \geq \mathbf{7 5 )}\end{array}$ & 67 \\
\hline
\end{tabular}

After conducting a reflection, it was revealed that a gap between the extensive listening and classroom activities might explain the major cause for the failure of the Cycle 1. In this cycle, the classroom activities were not related to the extensive listening since the students were only assigned to submit their weekly portfolio report without follow up activities in the classroom. Moreover, the first cycle was considered ineffective due to conventional submission technique (video/audio soft file and printed portfolio report). Some changes were then made to be implemented in the next cycle.

\section{Cycle 2}

After some revisions were made, Cycle 2 was conducted and a test was administered at the end of the cycle. The test result in Cycle 2 indicated that the average score increased to be 78.36 with16 students reached the minimum score of 75 meaning that $73 \%$ of the students reached the standard minimum score, meaning that the criterion of success was achieved. Detailed score is presented in Table 2.

Table 2 Students' Test Score in Cycle 2

\begin{tabular}{clcc}
\hline NO. & & NAME & SCORE \\
\hline 1 & DAM & 86 \\
2 & RWP & 74 \\
3 & GAH & 85 \\
4 & N & 83 \\
5 & QA & 83 \\
6 & IM & 83 \\
7 & PMH & 85 \\
8 & SM & 88 \\
9 & ARD & 85 \\
10 & TW & 86 \\
11 & DH & 76 \\
12 & TW & 88 \\
13 & AM & 74 \\
14 & DDJ & 72 \\
\hline
\end{tabular}




\begin{tabular}{clc}
\hline 15 & FHA & 93 \\
16 & IS & 78 \\
17 & S & 65 \\
18 & AM & 65 \\
19 & ES & 76 \\
20 & NSS & 32 \\
21 & NCH & 88 \\
22 & VAF & 79 \\
\hline Average Score & $\mathbf{7 8 . 3 6}$ \\
\hline Percentage $(\%)$ & $\mathbf{7 3}$ \\
(The score of $\geq \mathbf{7 5})$ & \\
\hline
\end{tabular}

\section{DISCUSSION}

As shown in the previous section, this action research must be done in two cycles since the test result in Cycle 1 did not meet the criteria of success. In the reflection, it was revealed that there was a gap between the extensive listening and classroom activities. In this cycle, the students were only asked to submit their weekly portfolio report without follow up activities in the classroom. In other words, the classroom activities were not related to the extensive listening. In addition, the first cycle was not effective because of the report was submitted conventionally in the form of video/audio soft file and printed portfolio report. It took time only to collect them, and some students did not submit their assignments with various reasons. Based on the reflection, some changes were made to be implemented in the next cycle. The first change was in terms of engaging the students with follow up activities such as group discussion, presentation, and role play. The second change was the use of educational online platform to facilitate the students in submitting their weekly assignments. The last is vocabulary enrichment.

Based on the research result presented earlier, it is obvious that extensive listening provides positive influence on the students' listening skill. It is in line with the finding of some previous studies (Reinders\&Cho, 2010; Onoda, 2012; Chang \&Millett, 2013; Ducker, 2013; Hapsari\&Ratri, 2013; Bozan, 2015; Mayora, 2017). With extensive listening activities, it was found that students' listening score increased quite significantly in Cycle 1 though it did not attain the criterion of success yet $(55 \%$ students got $\geq 75$ with the average score of 75.36). In Cycle 2, their score was also increased and achieved the criteria of success ( $73 \%$ students obtained score of $\geq 75$ with the average score of 78.36).

However, itis worth to note that linking extensive listening with classroom activities is the most promising combination to optimize the learning process. As it is proven, the criterion of success was reached after the engagement of extensive listening with the classroom activities. Students found it more motivated to do the extensive listening when it was further discussed or continued with follow up activities in the classroom rather than when it was done in isolated way. The follow-up were done in the form of various and more collaborative activities such as watching the students' song cover video and reviewing it, sharing the best video/audio they listened the previous week and discussing the content with group mates, and practicing a procedure text. With these kinds of activities, the students' involvement in classroom activities also improved.This confirms the research finding reported by HapsariandRatri (2013). Not only that, through collaborative learning, students are trained to be more sociable and to be able to share with others and at the same time, they can be independent learners (Widodo\&Rozak, 2016). 
An interesting finding appeared when blended learning model was used to replace the "only face-to-face classroom" and the submission procedure was changed from direct submission into online. An online learning platform similar to Facebook namely Edmodo was used as digital portfolio, where students could submit their weekly assignment as well as share ideas or documents (audio/video) anytime and anywhere. With this application, the students showed a more positive attitude toward the extensive listening and listening course in general. Moreover, they could decide the topic through the poll feature provided on Edmodo, which allowed them to learn what they wanted to. The students' positive attitude can be seen from the submission percentage, which increased from overall $74 \%$ to nearly $90 \%$. The submission did not reach perfect $100 \%$ since some students were late to turn in the assignment, while the due time was automatically locked. The basic reason for the lateness lied on the Internet access. This finding is in line with what Candrasari (2015) found that the use of Edmodo encourages the students to be more active, motivated, and joyful in the learning process.

In addition, vocabulary enrichment is also influential to the students' better achievement. One of the problems encountered by students is terms of text factor involving type of text, picture cue access, and unfamiliarity with certain vocabulary (Li \&Renandya, 2012). Pronunciation, according to Hamouda (2013) is also a crucial problem that often leads to listening breakdown. Therefore, after voting for the topic using poll feature on Edmodo, the students were given a vocabulary list related to the selected topic. The students were asked to find the meaning of each word based on the context and to check the pronunciation. Those activities were to make the students more familiar with the vocabulary and the pronunciation. With these, theycouldunderstand the listening text more easily.

Finally, when a poll asking their perception about Edmodo was made, 95\% of the students gave positive response toward the use of this application. The vast majority of them stated that it is easier, simpler, and faster to submit their assignment. The opponents of this application (5\%) mainly provide limited Internet access as their valid reason. The thing that might best explain this result is the students' dependence on gadget and virtual world. They mostly spend their time doing online activities; thus, engaging them in an online learning can be the most possible and feasible way to advance their learning in this digital era. This finding provides a supporting evidence that blended learning can lead to the enhancement of students' listening skill, and this learning model is satisfactorily accepted by the millennial students (Bañados, 2006; Abdullah, 2015; Alshaikhi\&Madini, 2016; Banditvilai, 2016; Lebedevaat.al., 2017).

\section{CONCLUSION AND SUGGESTION}

The finding of this research implies that the implementation of blended learning approach with portfolio-based extensive listening activity can significantly enhance the students' listening skill. However, a more optimum result is obtained when there is no gap between the extensive listening and the classroom activities. In addition, the students' dependence on gadget and Internet might explain the positive attitude toward the implementation of blended learning model. The use of educational online applications provides the students with a wider chance to have target language exposure. However, to make the online activities more alive, there is a need of more specific and structured instructions that must be done by the students ina virtual mode before having face-to-face meetings. 


\section{REFERENCES}

Abdullah, H. M. (2015). Improving listening comprehension for EFL pre-intermediate students through a blended learning strategy. International Journal of Social, Behavioral, Educational, Economic, Business and Industrial Engineering, 9(10), 3666-3674.

Alshaikhi, D., \& Madini, A. A. (2016). Saudi female students' and teachers' perception of utilizing Podcasts to improve extensive listening. International Journal of Educational Investigations, 3(6), 21-41. Retrieved from https://www.researchgate.net/publication/311052652

Bañados, E. (2006). A blended-learning pedagogical model for teaching and learning EFL successfully through an online interactive multimedia environment. CALICO Journal, 533-550.

Banditvilai, C. (2016). Enhancing students' language skills through blended learning. The Electronic Journal of e-Learning, 14(3), 220-229.

Bozan, E. (2015). The effects of extensive listening for pleasure on the proficiency level of foreign language learners in an input-based setting. Kansas: Department of Curriculum and Teaching and the Graduate Faculty of the University of Kansas. Retrieved from http://kuscholarworks.ku.edu

Candrasari, M. (2015). The use of Edmodo website to improve students' writing skill (Classroom Action Research of the tenth grade students of SMKN 1 Wonosegoro in academic 2015/2016). State Institute for Islamic Studies (IAIN) Salatiga. Salatiga: English Education Department, Teacher Training and Education Faculty. Retrieved from erepository.perpus.iainsalatiga.ac.id/396/1/Mulya\%20Candrasari_11311048.pdf

Chang, A. C.-S., \& Millett, S. (2013). The effect of extensive listening on developing L2 listening fluency: Some hard evidence. ELT Journal, 68(1), 31-40. doi:10.1093/elt/cct052

Condruz-Băcescu, M. (2012). Blended learning-the future of learning in foreign languages. Synergy, 151-160.

Ducker, N. (2013). Self-directed Internet-based extensive listening portfolios. In N. Sonda, \& A. Krause (Ed.), JALT2012 (pp. 516-526). Tokyo: JALT.

Grgurović, M. (2011). Blended learning in an ESL class: A case study. CALICO Journal, 100-117.

Hamouda, A. (2013). An investigation of listening comprehension problems encountered by Saudi students in the EL listening classroom. International Journal of Academic Research in Progressive Education and Development, 2(2), 113-155.

Hapsari, Y., \& Ratri, D. P. (2013). Extensive listening: Let students experience learning by optimizing the use of authentic materials. Forum Ilmiah IX (Seminar dan Lokakarya Internasional) FPBS-UPI. Malang. Retrieved August 6, 2017, from http://fib.ub.ac.id

Lebedeva, M. Y., Koltakova, E. V., Khaleeva, O. N., \& Rusetskaya, M. (2017). Computerassisted language learning for the development of listening skills: A case study of pre-university Russian as a foreign language. International Journal of Applied Linguistics \& English Literature, 257-265. 
Li, W. \& Renandya, W. A. (2012). Effective approaches to teaching listening: Chinese EFL teachers' perspectives. The Journal of Asia TEFL, 9(4), 79-111. Retrieved from http://www.asiatefl.org

Mayora, C. A. (2017). Extensive listening in a Colombian University: Process, product, and perceptions. HOW, 24(1), 101-121. Retrieved from http://dx.doi.org/10.19183/how.24.1.311

Onoda, S. (2012). The effect of QuickListens and extensive listening on EFL listening skill development. Extensive Reading World Congress (pp. 176-179). Kyoto: Extensive Reading Foundation.

Poon, J. (2013). Blended learning: An institutional approach for enhancing students' learning experiences. MERLOT Journal of Online Learning and Teaching, 9(2), 271-289.

Reinders, H., \& Chou, M. Y. (2010). Extensive listening practice and input enhancement using mobile phones: Encouraging out-of-class learning with mobile phones. TESL-EJ, 14(2).

Richards, J. C. (2005). Second Thoughts on Teaching Listening. RELC Journal, 36(85), 86-92. doi:10.1177/0033688205053484

Stracke, E. (2007). A road to understanding:A qualitative study into why learners drop out of a blended language learning (BLL) environment. ReCALL, 19(1), 57-78.

Widodo, H. P., \& Rozak, R. R. (2016). Engaging student teachers in collaborative and reflective Oonline video-sssisted extensive listening in an Indonesian initial teacher education (ITE) context. Electronic Journal of Foreign Language Teaching, 13(2), 229-244. 